\title{
Label-free mass spectrometric analysis reveals complex changes in the brain proteome from the $m d x-4 c v$ mouse model of Duchenne muscular dystrophy
}

Sandra Murphy ${ }^{1 \dagger}$, Margit Zweyer ${ }^{2 \dagger}$, Michael Henry ${ }^{3}$, Paula Meleady ${ }^{3}$, Rustam R. Mundegar ${ }^{2}$, Dieter Swandulla ${ }^{2}$ and Kay Ohlendieck ${ }^{*}$

\begin{abstract}
Background: X-linked muscular dystrophy is a primary disease of the neuromuscular system. Primary abnormalities in the Dmd gene result in the absence of the full-length isoform of the membrane cytoskeletal protein dystrophin. Besides progressive skeletal muscle wasting and cardio-respiratory complications, developmental cognitive deficits and behavioural abnormalities are clinical features of Duchenne muscular dystrophy. In order to better understand the mechanisms that underlie impaired brain functions in Duchenne patients, we have carried out a proteomic analysis of total brain extracts from the $m d x-4 c v$ mouse model of dystrophinopathy.

Results: The comparative proteomic profiling of the $m d x-4 c v$ brain revealed a significant increase in 39 proteins and a decrease in 7 proteins. Interesting brain tissue-associated proteins with an increased concentration in the $m d x-4 C V$ animal model were represented by the glial fibrillary acidic protein GFAP, the neuronal $\mathrm{Ca}^{2+}$-binding protein calretinin, annexin AnxA5, vimentin, the neuron-specific enzyme ubiquitin carboxyl-terminal hydrolase isozyme L1, the dendritic spine protein drebrin, the cytomatrix protein bassoon of the nerve terminal active zone, and the synapse-associated protein SAP97. Decreased proteins were identified as the nervous system-specific proteins syntaxin-1B and syntaxinbinding protein 1, as well as the plasma membrane $\mathrm{Ca}^{2+}$-transporting ATPase PMCA2 that is mostly found in the brain cortex. The differential expression patterns of GFAP, vimentin, PMCA2 and AnxA5 were confirmed by immunoblotting. Increased GFAP levels were also verified by immunofluorescence microscopy.

Conclusions: The large number of mass spectrometrically identified proteins with an altered abundance suggests complex changes in the $m d x-4 c v$ brain proteome. Increased levels of the glial fibrillary acidic protein, an intermediate filament component that is uniquely associated with astrocytes in the central nervous system, imply neurodegeneration-associated astrogliosis. The up-regulation of annexin and vimentin probably represent compensatory mechanisms involved in membrane repair and cytoskeletal stabilization in the absence of brain dystrophin. Differential alterations in the $\mathrm{Ca}^{2+}$-binding protein calretinin and the $\mathrm{Ca}^{2+}$-pumping protein PMCA2 suggest altered $\mathrm{Ca}^{2+}{ }^{-}$-handling mechanisms in the Dp427-deficient brain. In addition, the proteomic findings demonstrated metabolic adaptations and functional changes in the central nervous system from the dystrophic phenotype. Candidate proteins can now be evaluated for their suitability as proteomic biomarkers and their potential in predictive, diagnostic, prognostic and/or therapy-monitoring approaches to treat brain abnormalities in dystrophinopathies.
\end{abstract}

\footnotetext{
*Correspondence: kay.ohlendieck@nuim.ie

${ }^{\dagger}$ Sandra Murphy and Margit Zweyer contributed equally

${ }^{1}$ Department of Biology, Maynooth University, National University

of Ireland, Maynooth, Co. Kildare, Ireland

Full list of author information is available at the end of the article
} 
Keywords: Annexin, Ca ${ }^{2+}$-ATPase PMCA2, Dystrophinopathy, Glial fibrillary acidic protein, Glyosis, Intermediate filament, Mental retardation, Vimentin, von Willebrand factor

\section{Background}

Proteome-wide studies play a central role in the systematic assessment of diseases of childhood. Biomedical surveys based on mass spectrometry-based proteomics can provide a comprehensive overview of molecular changes that underlie paediatric disorders and identify novel proteomic biomarker candidates for improving predictive, diagnostic, prognostic and therapy-monitoring procedures [1-3]. Duchenne muscular dystrophy is a paediatric disease of the skeletal musculature that is characterized by a variety of abnormalities in muscle tissues, including changes in myofibre size, central nucleation, fibre branching, hyper-contractility, necrosis, inflammation, fatty deposition and myofibrosis [4-6]. Mutations or genetic rearrangements in the X-chromosomal Dmd gene encoding the membrane cytoskeletal protein dystrophin are the underlying cause for highly progressive skeletal muscle wasting [7]. The reduction in dystrophinassociated glycoproteins is a hallmark of fibre degeneration and closely linked to the loss of sarcolemmal integrity in muscular dystrophy [8-10]. Associated complications in Duchenne patients are cardio-respiratory impairments, orthopaedic problems causing muscle contractures and scoliosis, endocrinological issues related to growth and weight gain, as well as gastrointestinal, renal, urinary and ophthalmological complications [11-14] that are taken into account in the current treatment and management of dystrophinopathies [15-17].

The elucidation of the molecular and cellular mechanisms of the multi-systemic manifestation of Duchenne muscular dystrophy in non-muscle tissues is complicated by the existence of several promoters that drive the tissue-specific expression of dystrophin isoforms ranging in molecular mass from 71 to $427 \mathrm{kDa}$ [18]. Brain dystrophins and their associated glycoproteins are mainly involved in neuronal excitability, signal integration, synaptic modulation and neuronal plasticity [19-22]. In the nervous system, major dystrophin isoforms include Dp71, Dp140 and Dp427 [23]. Full-length brain dystrophins are present in neurons of the cerebral cortex and the hippocampus, as well as in cerebellar Purkinje cells [24-27] and exhibit similar biochemical properties as the muscle Dp427 isoform [28, 29]. The shorter dystrophin isoform Dp140 is most highly expressed during brain development [30] and the most abundant brain dystrophin, Dp71, is present in both neurons and glia cells in the dentate gyrus and the olfactory bulb [31-33].
The presence of specific dystrophins in the central nervous system is of considerable interest, since cognitive impairments and emotional disturbances are established clinical features of dystrophinopathies [34-36]. Mental retardation and behavioural impairments seem to be secondary to physical handicap [37-40] and do not correlate with the progressive nature of the neuromuscular pathology in X-linked muscular dystrophy [41-44]. Cognitive impairments seem to affect memory, attention, language and emotion to a differing degree in individuals suffering from dystrophinopathies [45-47]. In analogy to Duchenne patients, the $m d x$ animal model of dystrophinopathy shows significant alterations in associative learning patterns and deficits in long-term consolidation memory [48-50], as well as metabolic and cellular abnormalities in distinct brain regions [51-53].

In order to evaluate the degree of proteome-wide changes in the central nervous system of the dystrophindeficient mouse, we have carried out a comparative labelfree mass spectrometric analysis of the $m d x-4 c v$ brain versus wild type brain. Systematic proteomic studies have previously established a number of changes in proteins involved in energy metabolism, cellular signalling, the extracellular matrix, cytoskeletal networks and the cellular stress response in dystrophic skeletal and cardiac muscles [54]. Here, we have applied this technology-driven approach to extend these studies to the pathophysiological mechanisms that facilitate impaired brain functions in X-linked muscular dystrophy. Highly relevant proteins affected in brain tissue from dystrophic mice were identified as the glial fibrillary acidic protein GFAP, calretinin, annexin AnxA5, vimentin, syntaxin, drebrin, bassoon and the plasma membrane $\mathrm{Ca}^{2+}$-ATPase PMCA2.

\section{Results and discussion}

Intellectual impairments and emotional disturbances are clearly present in Duchenne patients [45], although these clinical features are non-progressive and do not affect all dystrophic children [37]. Besides the unknown mechanisms that underlie this differential occurrence of neurological issues within the Duchenne patient cohort, other crucial unanswered questions remain in relation to the molecular and cellular pathogenesis of brain abnormalities. Importantly, it is not currently clear whether a pathophysiological hierarchy exists between developmental issues on the one hand and cycles of neurodegeneration and astroglyosis on the other hand in the central nervous system of patients afflicted with X-linked 
muscular dystrophy [46]. It was therefore of interest to use an unbiased and technology-driven approach to attempt a systematic evaluation of proteome-wide changes in affected brain tissue. In general, comparative proteomics has the potential to identify complex changes within cellular systems on a more global basis as compared to individual and hypothesis-driven biochemical, cell biological or physiological investigations. The proteomic profiling of the $m d x-4 c v$ brain presented here has successfully detected significant changes in a number of representative serum and brain proteins.

\section{Label-free LC-MS/MS analysis of mouse brain extracts}

An overview of the comparative proteomic analysis of the wild type brain versus the $m d x-4 c v$ brain employing label-free mass spectrometry is given in Fig. 1. The proteomic assessment of the mouse brain identified 4878 unique peptides belonging to 1359 individual protein species in the wild type and 4311 unique peptides belonging to 1213 individual protein species in the $m d x-4 c v$ phenotype. The fact that this technique was successfully applied to study the mouse brain proteome is exemplified by the mass spectrometric identification of 2 well-established brain proteins, BASP-1 and SNP-25. The growthassociated brain acid soluble protein BASP-1 (Q91XV3; also known as neuronal axonal membrane protein NAP22 ) is a membrane-attached signalling protein of growth cones that form the tips of elongating axons [55]. Its sequence was covered in the wild type brain by 16 unique peptides with $87 \%$ coverage and in the $m d x-4 c v$ brain by 17 unique peptides with $87 \%$ coverage. The synaptosome-associated protein SNP-25 (P60879) is associated

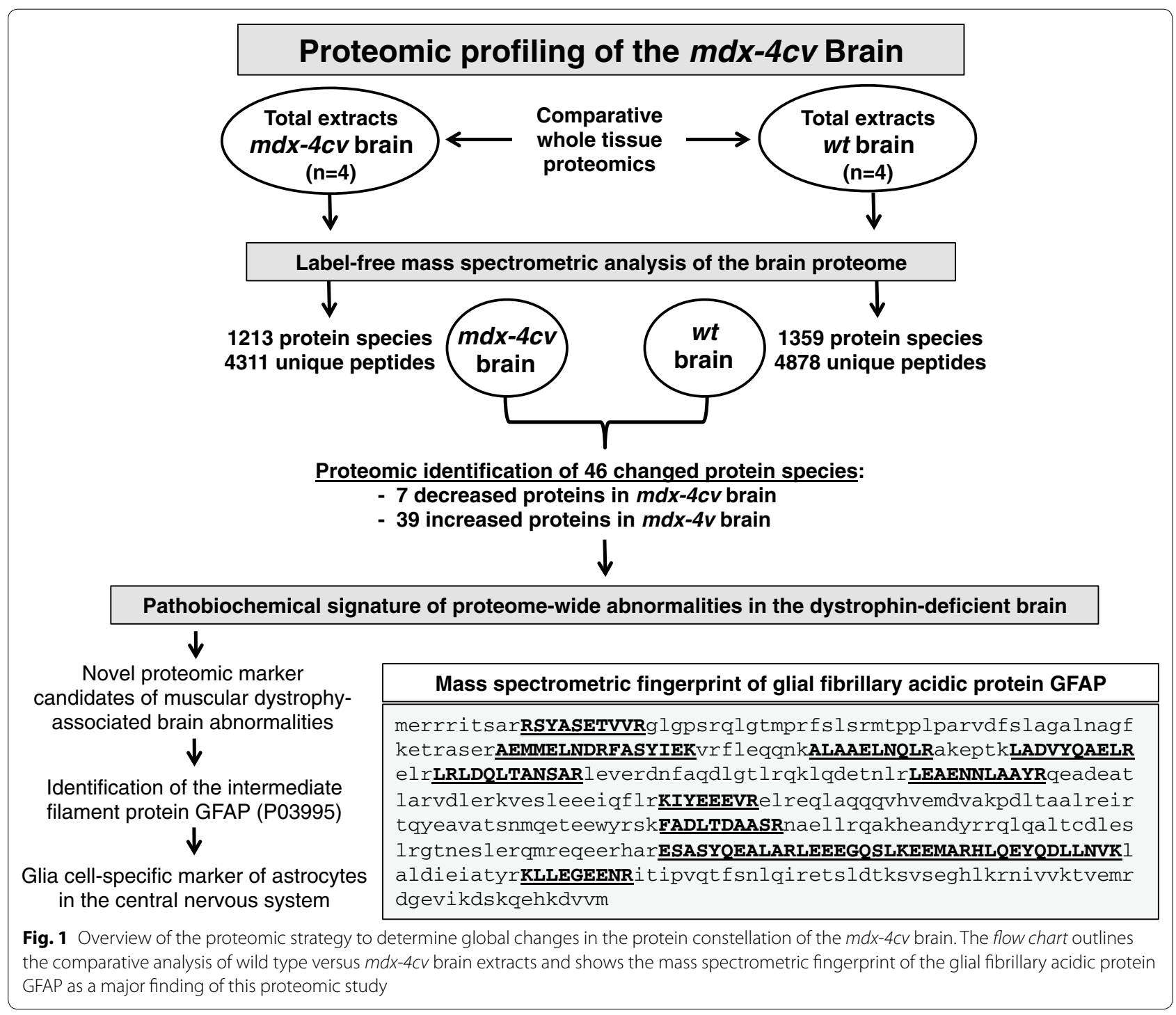


with proteins involved in vesicle docking and membrane fusion and plays a critical role in synaptic function and the molecular regulation of neurotransmitter release [56]. SNP-25 was covered in the wild type brain by 13 unique peptides with $47 \%$ coverage and in the $m d x-4 c v$ brain by 11 unique peptides with $46 \%$ coverage. In contrast to gel-based studies, the usage of liquid chromatography in combination with highly sensitive label-free mass spectrometry identified both extremely large proteins and highly hydrophobic integral membrane proteins. These types of brain proteins are usually underrepresented in two-dimensional gel electrophoresis. For example, the sequence of the $500-\mathrm{kDa}$ intermediate filament-binding protein plectin (Q9QXS1) [57] was covered in the wild type brain by 18 unique peptides with approximately $5 \%$ coverage and in the $m d x-4 c v$ brain by 17 unique peptides with approximately $4 \%$ coverage. Remarkably, the five main subunits of the plasmalemmal $\mathrm{Na}^{+} / \mathrm{K}^{+}$-ATPase [58] were all identified in brain extracts. The alpha-1 (Q8VDN2), alpha-2 (Q6PIE5), alpha-3 (Q6PIC6), beta-1 (P14094) and beta-2 (P14231) subunits were covered in the wild type brain by $13,17,20,9$ and 4 unique peptides with 20,21, 27, 19 and $10 \%$ coverage, respectively. These findings demonstrate the outstanding performance of the LTQ Orbitrap XL mass spectrometer used in this comparative whole tissue proteomic study.

\section{Label-free LC-MS/MS analysis of changed proteins in total $m d x-4 c v$ brain extracts}

The proteomic comparison of total brain extracts from wild type versus $m d x-4 c v$ mice using label-free LC-MS/ MS analysis identified 46 affected protein species in the dystrophic phenotype (Fig. 1). Table 1 lists the accession number, protein name, peptide count, confidence score, Anova value and fold change of individual proteins identified by mass spectrometry. An increased abundance was established for 39 proteins and 7 proteins showed a decreased concentration. Of considerable interest was the proteomic identification of elevated serum proteins, especially the confirmation of previously established biomarkers of muscular dystrophy. Increased proteins that are mostly associated with plasma and the extracellular space were identified as hemopexin (beta-1B-glycoprotein), alpha-2-HS-glycoprotein (fetuin-A), alpha-1-antitrypsin 1-1 and 1-2, hemoglobin alpha and beta-1, apolipoprotein A-I, albumin and serotransferrin. The increase of this class of soluble protein is most likely due to disease-related changes in the concentration levels of distinct plasma proteins, but could also be partially associated with altered capillarisation, local cellular damage, disturbed homeostasis, impaired regulatory mechanisms, proteolytic processes and/or inflammatory responses.
Immunofluorescence microscopy of brain sections using an antibody to von Willebrand factor (vWF) indicated changes in the vascularization of the $m d x-4 c v$ brain (Fig. 2). The dot-shaped labelling of Weibel-Palade bodies [59], that act as specific intracellular storage organelles for vWF molecules in the vessel endothelium [60], can be clearly seen as distinct subcellular structures in normal brain sections (Fig. 2a). Under normal conditions, multimeric vWF molecules assemble into tubular structures within Weibel-Palade bodies in the inner lining of blood vessels. However, when vWF molecules are released they unfold into strings and play a critical role in hemostasis, inflammation, regulation of vascular tone and angiogenesis [61]. The $m d x-4 c v$ brain showed, besides punctate Weibel-Palade bodies, also a large number of string-like structures that contain vWF molecules (Fig. 2b). Since this type of transformation is indicative of a response of the endothelium to pathophysiological changes in its micro environment [60], dystrophin deficiency appears to trigger the subcellular translocation of Weibel-Palade bodies and the release of vWF. Therefore structural distension, vascular damage and inflammatory processes appear to exist at the blood-tissue interface in the $m d x-4 c v$ brain. This would agree with the cell biological analysis of tight junction and glial markers in the $m d x$ brain, which showed that microvessels are lined by altered endothelial cells with open tight junctions and swollen glial processes. The perivascular glial endfeet zone was shown to contain cellular debris and was enveloped by degenerating microvessels [62].

The approximately fivefold increase of hemopexin, an abundant serum glycoprotein that binds free heme, is a well-established disease indicator in the plasma from Duchenne muscular dystrophy patients and carriers of this neuromuscular disorder [63, 64]. Since serotransferrin is responsible for the efficient binding and transportation of iron throughout the circulatory system [65], its increased concentration could be linked to an altered iron metabolism in the $m d x$ - $4 c v$ brain. The elevated levels of haemoglobin and albumin suggest a potential shift to higher levels of oxygen supply and fatty acid utilization. Interestingly, antitrypsin appears to be increased in brain tissue. This serum protein functions both as a protective anti-protease and a crucial anti-inflammatory factor [66], suggesting the triggering of a protective mechanism within Dp427-lacking tissue in response to neuronal degeneration and brain inflammation. The identification of fetuin-A also agrees with the pathological status of the $m d x-4 c v$ mouse, since this multi-functional protein has been previously identified as a general biomarker for neurodegenerative disease [67]. 
Table 1 Changed proteins in $m d x-4 c v$ brain tissue as revealed by label-free LC-MS/MS analysis

\begin{tabular}{|c|c|c|c|c|c|}
\hline Accession number & Protein name & Peptide count & Confidence score & Anova (p) & Fold change \\
\hline Q91X72 & Hemopexin & 3 & 131.20 & 0.00116 & 5.64 \\
\hline P29699 & Alpha-2-HS-glycoprotein & 2 & 125.19 & 0.00171 & 3.47 \\
\hline P22599 & Alpha-1-antitrypsin 1-2 & 2 & 114.76 & 0.01445 & 3.29 \\
\hline P02088 & Hemoglobin subunit beta-1 & 3 & 260.19 & 0.00104 & 3.24 \\
\hline P01942 & Hemoglobin subunit alpha & 5 & 370.80 & 0.00021 & 3.22 \\
\hline Q00623 & Apolipoprotein A-I & 8 & 316.96 & 0.00522 & 2.88 \\
\hline P07758 & Alpha-1-antitrypsin 1-1 & 4 & 108.27 & 0.01739 & 2.52 \\
\hline P07724 & Serum albumin & 16 & 1174.47 & 0.00049 & 2.51 \\
\hline Q923D2 & Flavin reductase (NADPH) & 3 & 203.95 & 0.00171 & 2.51 \\
\hline Q92111 & Serotransferrin & 8 & 374.58 & 0.01661 & 2.18 \\
\hline P03995 & Glial fibrillary acidic protein & 8 & 491.51 & 0.03531 & 2.00 \\
\hline Q08331 & Calretinin & 2 & 94.24 & 0.04022 & 1.93 \\
\hline P48036 & Annexin A5 & 2 & 132.70 & 0.03204 & 1.56 \\
\hline P20152 & Vimentin & 2 & 213.31 & 0.00440 & 1.55 \\
\hline Q9R0P9 & Ubiquitin carboxyl-terminal hydrolase isozyme L1 & 3 & 165.79 & 0.02308 & 1.51 \\
\hline P46460 & Vesicle-fusing ATPase & 2 & 134.05 & 0.00110 & 1.44 \\
\hline Q9D0E1 & Heterogeneous nuclear ribonucleoprotein M & 3 & 63.46 & 0.01490 & 1.44 \\
\hline 008788 & Dynactin subunit 1 & 2 & 126.53 & 0.01025 & 1.44 \\
\hline P38647 & Stress-70 protein, mitochondrial & 6 & 476.79 & 0.00175 & 1.42 \\
\hline P48758 & Carbonyl reductase [NADPH] 1 & 2 & 119.09 & 0.01333 & 1.42 \\
\hline P00920 & Carbonic anhydrase 2 & 2 & 135.96 & 0.02814 & 1.42 \\
\hline P14733 & Lamin-B1 & 2 & 150.58 & 0.02918 & 1.41 \\
\hline Q6IRU5 & Clathrin light chain B & 2 & 125.00 & 0.04203 & 1.40 \\
\hline Q8R3V5 & Endophilin-B2 & 4 & 201.90 & 0.02055 & 1.39 \\
\hline Q8QZT1 & Acetyl-CoA acetyltransferase, mitochondrial & 4 & 215.23 & 0.00680 & 1.36 \\
\hline P27773 & Protein disulfide-isomerase A3 & 5 & 295.10 & 0.01295 & 1.35 \\
\hline Q91VR2 & ATP synthase subunit gamma, mitochondrial & 4 & 251.82 & 0.00255 & 1.35 \\
\hline Q6ZWY9 & Histone $\mathrm{H} 2 \mathrm{~B}$ type $1-\mathrm{C} / \mathrm{E} / \mathrm{G}$ & 2 & 121.60 & 0.04212 & 1.34 \\
\hline Q61171 & Peroxiredoxin-2 & 2 & 141.40 & 0.01279 & 1.33 \\
\hline Q9D051 & $\begin{array}{l}\text { Pyruvate dehydrogenase E1 component subunit beta, mito- } \\
\text { chondrial }\end{array}$ & 4 & 262.12 & 0.00408 & 1.32 \\
\hline O35737 & Heterogeneous nuclear ribonucleoprotein $\mathrm{H}$ & 2 & 100.27 & 0.01665 & 1.31 \\
\hline Q03265 & ATP synthase subunit alpha, mitochondrial & 6 & 480.06 & 0.00581 & 1.30 \\
\hline P20029 & 78 kDa glucose-regulated protein & 2 & 150.07 & 0.02510 & 1.29 \\
\hline Q9QXS6 & Drebrin & 3 & 142.38 & 0.01934 & 1.28 \\
\hline P62259 & 14-3-3 protein epsilon & 2 & 103.43 & 0.02864 & 1.27 \\
\hline O88737 & Protein bassoon & 3 & 215.46 & 0.01328 & 1.25 \\
\hline Q811D0 & Disks large homolog 1 & 2 & 110.76 & 0.00639 & 1.25 \\
\hline P14873 & Microtubule-associated protein 1B & 2 & 126.07 & 0.00500 & 1.24 \\
\hline P16546 & Spectrin alpha chain, non-erythrocytic 1 & 3 & 197.38 & 0.01491 & 1.24 \\
\hline P61264 & Syntaxin-1B & 4 & 356.83 & 0.00121 & -1.28 \\
\hline Q02053 & Ubiquitin-like modifier-activating enzyme 1 & 2 & 131.59 & 0.04436 & -1.41 \\
\hline P51150 & Ras-related protein Rab-7a & 3 & 106.89 & 0.01101 & -1.51 \\
\hline P07901 & Heat shock protein HSP 90-alpha & 2 & 109.14 & 0.03836 & -1.54 \\
\hline O08599 & Syntaxin-binding protein 1 & 4 & 315.93 & 0.01966 & -1.54 \\
\hline Q9WV92 & Band 4.1-like protein 3 & 3 & 218.67 & 0.00892 & -1.90 \\
\hline Q9R0K7 & Plasma membrane calcium-transporting ATPase 2 & 2 & 108.25 & 0.01784 & -2.77 \\
\hline
\end{tabular}



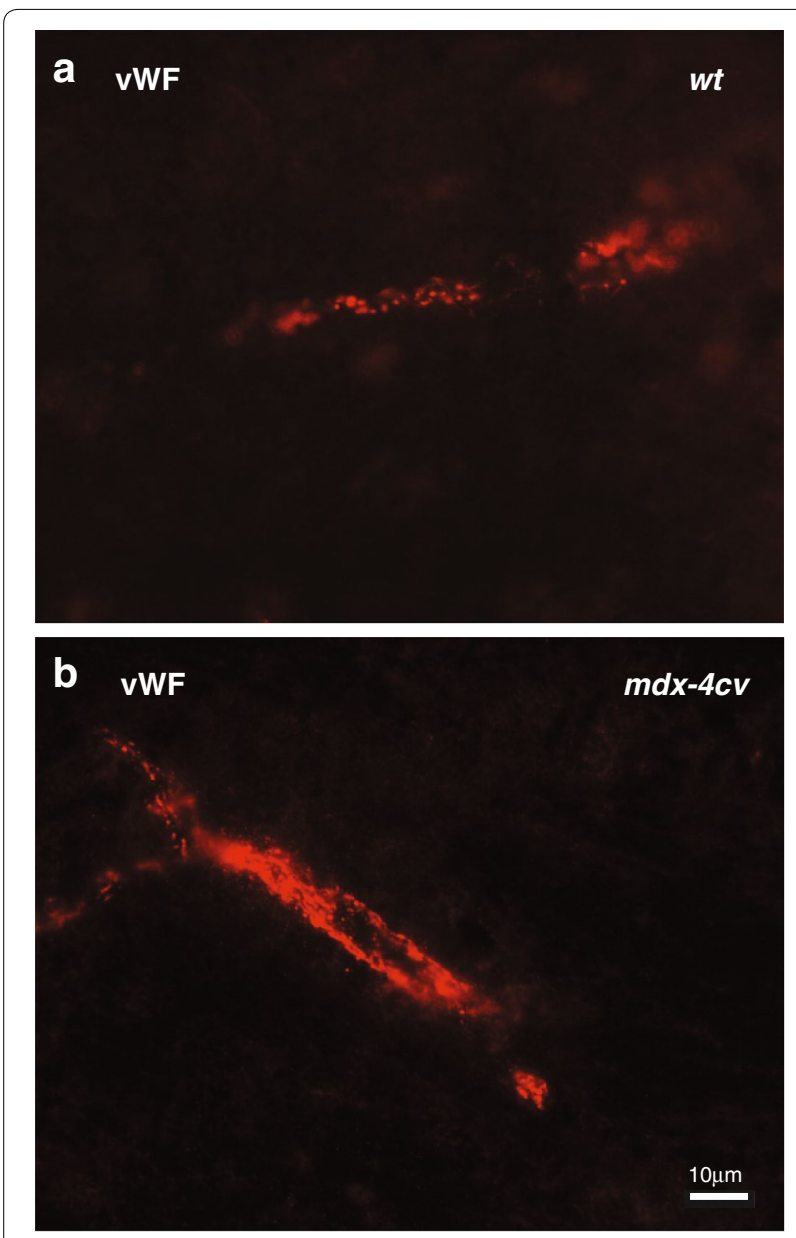

Fig. 2 Immunofluorescence microscopical analysis of von Willebrand factor in normal versus $m d x-4 c v$ brain. Shown is the immunofluorescence labelling of brain sections using an antibody to von Willebrand factor (vWF) in wild type a versus $m d x-4 c v \mathbf{b}$ cortex. Dot-like staining patterns are seen in both normal and $m d x-4 c v$ brain sections and represent Weibel-Palade bodies [61] that function as intracellular storage organelles for vWF molecules in the vessel endothelium. The $m d x-4 C v$ brain shows also a large number of string-like structures that contain VWF molecules, which is indicative of structural alterations, vascular damage and inflammatory processes at the blood-tissue interface in the $m d x-4 c v$ brain. Bar equals $10 \mu m$

\section{Altered brain tissue-associated proteins in the $m d x-4 c v$ mouse model of dystrophinopathy}

Interesting brain tissue-associated proteins with an increased concentration in the $m d x-4 c v$ animal model of Duchenne muscular dystrophy were represented by flavin reductase, glial fibrillary acidic protein GFAP, the neuronal $\mathrm{Ca}^{2+}$-binding protein calretinin, annexin AnxA5, vimentin, the neuron-specific enzyme ubiquitin carboxyl-terminal hydrolase isozyme L1, vesicle-fusing ATPase, heterogeneous nuclear ribonucleoproteins $\mathrm{M}$ and $\mathrm{H}$, dynactin, the 75 and $78 \mathrm{kDa}$ glucose-regulated proteins (mitochondrial chaperones HspA9/GRP-75 and HspA5/Grp78), carbonyl reductase, carbonic anhydrase CA2, lamin-B1, clathrin, endophilin-B2, mitochondrial acetyl-CoA acetyltransferase, protein disulfide-isomerase PDI-A3, mitochondrial ATP synthase (alpha and gamma subunits), histone H2B, peroxiredoxin PRDX2, mitochondrial pyruvate dehydrogenase, the dendritic spine protein drebrin, 14-3-3 protein epsilon, the cytomatrix protein bassoon of the nerve terminals active zone, the synapse-associated protein SAP97 (disks large homolog 1), microtubule-associated protein 1B and spectrin (Table 1). Decreased brain proteins were identified as the nervous system-specific proteins syntaxin-1B and syntaxin-binding protein 1 , as well as the plasma membrane $\mathrm{Ca}^{2+}$-transporting ATPase PMCA2 that is mostly found in the brain cortex. Other reduced brain-associated proteins included ubiquitin-like modifier-activating enzyme 1, ras-related protein Rab-7a, heat shock protein HSP 90-alpha (HSP90AA1) and 4.1-like protein 3 (Table 1).

\section{Distribution of protein changes in $m d x-4 c v$ brain tissue}

The distribution pattern of proteome-wide changes in $m d x-4 c v$ brain tissue in relation to altered protein classes is shown in Fig. 3. A standard bioinformatics software programme was used to illustrate overall protein changes. The application of the PANTHER analysis tool [68] revealed a certain degree of clustering of mass spectrometrically identified proteins with a changed concentration in $m d x$ $4 c v$ brain tissues. The most drastic alterations were shown to affect cytoskeletal proteins (14.3\%), which would agree with the underlying primary genetic abnormality in the membrane cytoskeletal component dystrophin. Considerable changes were shown to occur in the molecular classes of transfer/carrier proteins (10.7\%), hydrolases (8.9\%), enzyme modulators $(7.1 \%)$, molecular chaperones $(7.1 \%)$, transporters (7.1\%), oxidoreductases (7.1\%), nucleic acid binding proteins $(7.1 \%)$, membrane traffic proteins $(5.4 \%)$ and structural proteins (5.4\%). Relatively minor variations were identified for proteases (3.6\%), transferases (3.6\%), lyases, $(3.6 \%)$, receptors $(1.8 \%)$, transmembrane receptor regulatory/adaptor proteins (1.8\%), $\mathrm{Ca}^{2+}$-binding proteins $(1.8 \%)$, extracellular matrix proteins $(1.8 \%)$ and ligases $(1.8 \%)$. Select proteomic findings were further analysed by immunoblotting and immunofluorescence microscopy in order to independently verify the results from the comparative label-free LC-MS/MS study of brain tissue extracts from wild type versus $m d x-4 c v$ mice.

\section{Elevated levels of glial fibrillary acidic protein agrees with the pathobiochemical concept of neurodegeneration-related astrogliosis in the $m d x-4 c v$ brain}

The twofold increase of the glial fibrillary acidic protein (Table 1 ), which was identified by $48 \%$ sequence 


\section{Changed Protein Classes in the $m d x-4 c v$ Brain}

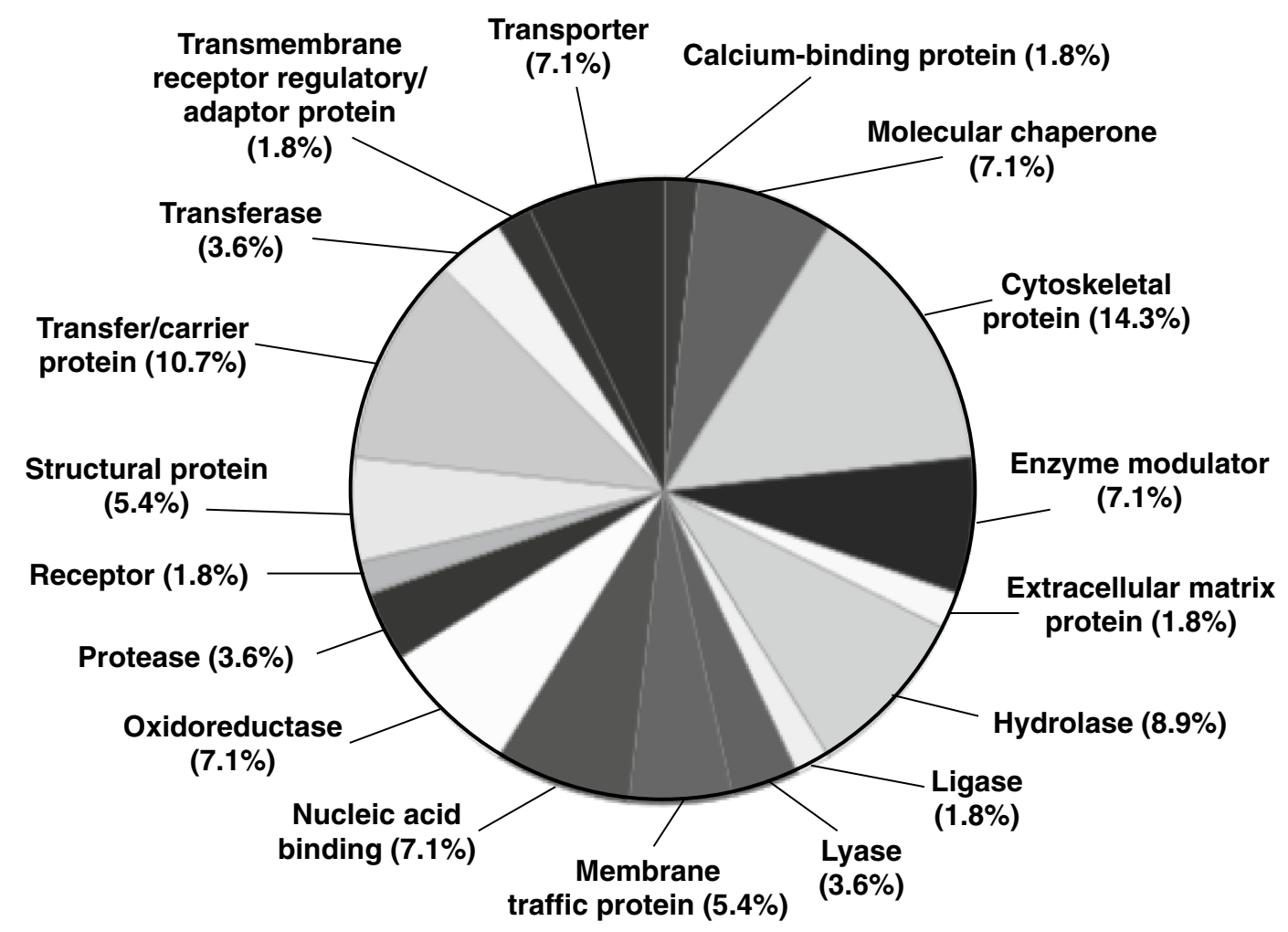

Fig. 3 Overview of changed protein classes in total tissue extracts from the $m d x-4 c v$ brain. In order to identify the clustering of protein classes based on the mass spectrometric analysis of crude extracts from wild type versus $m d x-4 c v$ brain specimens (Table 1), the bioinformatics software programme PANTHER [68] was used

coverage (Fig. 1), is an interesting proteomic finding of considerable pathobiochemical importance [69]. This brain protein is often referred to as GFAP [70] and functions as a major intermediate filament component that is specifically associated with astrocytes in the central nervous system [71]. Importantly, an increased concentration of GFAP is an established indicator of glial scar formation in the field of neuropathology [72-74]. The independent verification of expression changes in GFAP in $m d x-4 c v$ brain tissue was carried out by both immunoblot analysis and immunofluorescence microscopy. Figure 4 illustrates the specificity of the antibody to GFAP used in immunoblotting. While the nuclear envelope marker lamin and the cytosolic enzyme lactate dehydrogenase are present in crude extracts from mouse liver, diaphragm, heart, leg muscles and brain tissue (Fig. 4b, c), GFAP was only detected in brain specimens (Fig. 4d). A silver-stained gel of the protein extracts from different tissues is presented in Fig. 4a. The immuno-labelling of GFAP molecules often results in the recognition of more than one band in one-dimensional gel electrophoresis. An immunoblot study of GFAP by Singh et al. [75] has shown a tight banding pattern of this glial marker with 2-3 protein bands with slightly differing electrophoretic mobility. In analogy, the antibody decoration of increasing amounts of mouse brain protein per gel lane, as shown in Fig. 4e, demonstrated that a broader immuno-labelled GFAP banding pattern occurs at higher protein amounts. Based on these findings, an intermediate amount of brain protein was used per lane for comparative studies.

The expression changes of GFAP in $m d x-4 c v$ brain tissue, as indicated by comparative proteomic profiling (Table 1), was confirmed by immunoblotting as illustrated in Fig. 5. The concentration of GFAP was found to be significantly elevated in the $m d x-4 c v$ brain. Standard gel electrophoretic analyses showed no major changes in the protein band pattern of wild type versus dystrophic preparations (Fig. 5a, f, i). In contrast to the expression of 


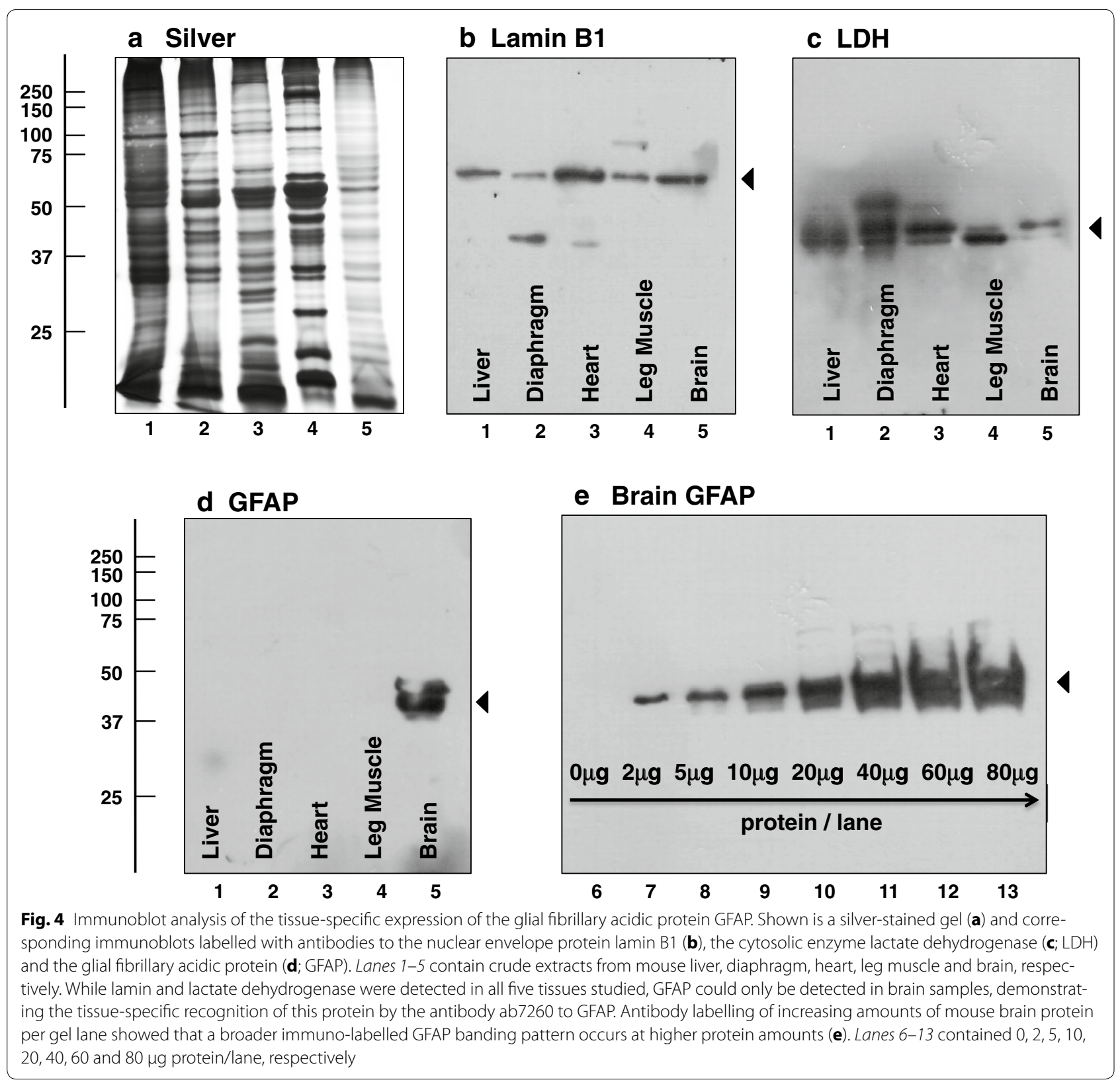

lactate dehydrogenase (used as a loading control), which does not appear to be affected in the Dp427-deficient brain (Fig. 5b, d, g, j), the abundance of the glia marker GFAP was shown to be significantly increased in 2- to 12 -month old $m d x-4 c v$ mice (Fig. $5 c$, e, h, k). The cell biological analysis of GFAP levels by immunofluorescence microscopy also confirmed the proteomic analysis of the $m d x-4 c v$ brain. As shown in Fig. 6, the cortex displayed a substantially higher labelling of GFAP in the dystrophin-deficient brain as compared to wild type. These immunoblotting and immunofluorescence microscopical results substantiated the proteomic findings presented in
Table 1 and agree with the idea of progressive astrogliosis as a consequence of progressive neurodegeneration in the $m d x-4 c v$ brain. Thus, the GFAP elevation probably reflects non-specific reactive gliosis [69-71] and the resulting glial scar formation may be linked to impaired brain functions in the $m d x$ mouse and Duchenne patients [46]. The constant loss of neurons and concomitant proliferation or hypertrophy of glial cells may be the underlying mechanism that triggers developmental cognitive deficits and behavioural abnormalities in Duchenne muscular dystrophy [45-47]. A previous case report of a Duchenne patient with severe mental retardation has 


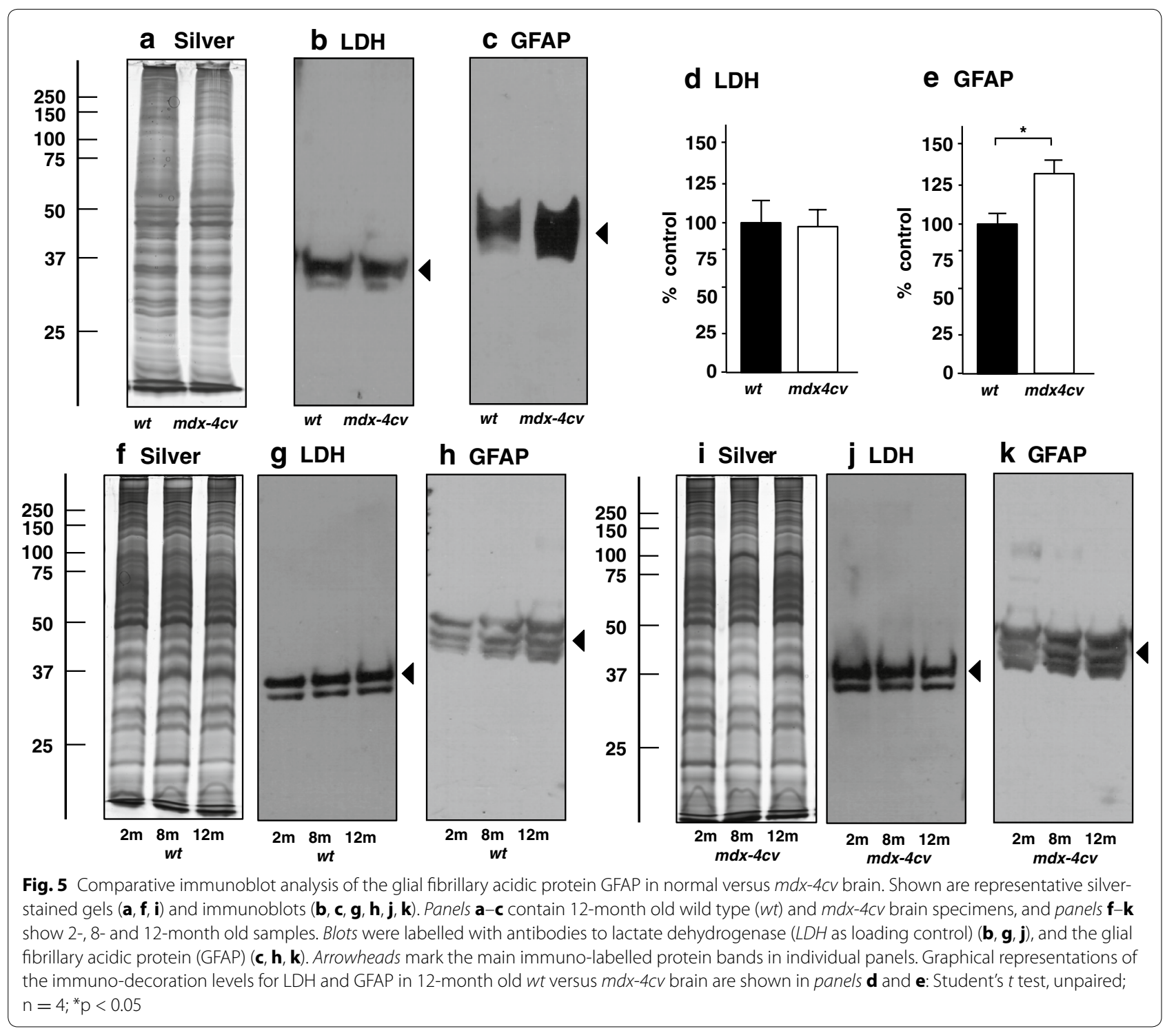

described multifocal glial nodules in the cerebral cortex. Proliferating glial cells showed intense immunoreactivity for GFAP and were suggested to be at least partially involved in the pathogenic mechanisms of mental retardation [76].

\section{Proteomic profiling suggests abnormal calcium handling, cytoskeletal restructuring and metabolic changes in the $m d x-4 c v$ brain}

The previous biochemical and cell biological characterization of the brain from dystrophic $m d x$ mice has demonstrated intricate changes in the development of the blood-brain barrier [62, 77], the regulation of the extracellular matrix [78] and the molecular arrangements within the glial dystrophin-associated signalling complex that contains the water channel aquaporin AQP4, the $\mathrm{K}^{+}$channel Kir-4.1 and agrin [79]. This suggests multifaceted cellular rearrangements within the dystrophin-lacking brain and the proteomic findings presented here have confirmed this complexity of pathobiochemical alterations. Noteworthy brain tissue-associated proteins with an increased concentration in the $m d x-4 c v$ animal model, besides the glial fibrillary acidic protein GFAP, were identified as the AnxA5 isoform of annexin, the intermediate filament protein vimentin and the nuclear envelope protein lamin LAM-B1. The immunoblot analysis presented in Fig. $7 \mathrm{a}-\mathrm{c}, \mathrm{e}-\mathrm{g}$ confirmed the general tendency of higher levels of these proteins, although only changes in annexin and vimentin were shown to be significant. In analogy to findings from dystrophic $m d x$ skeletal muscles 

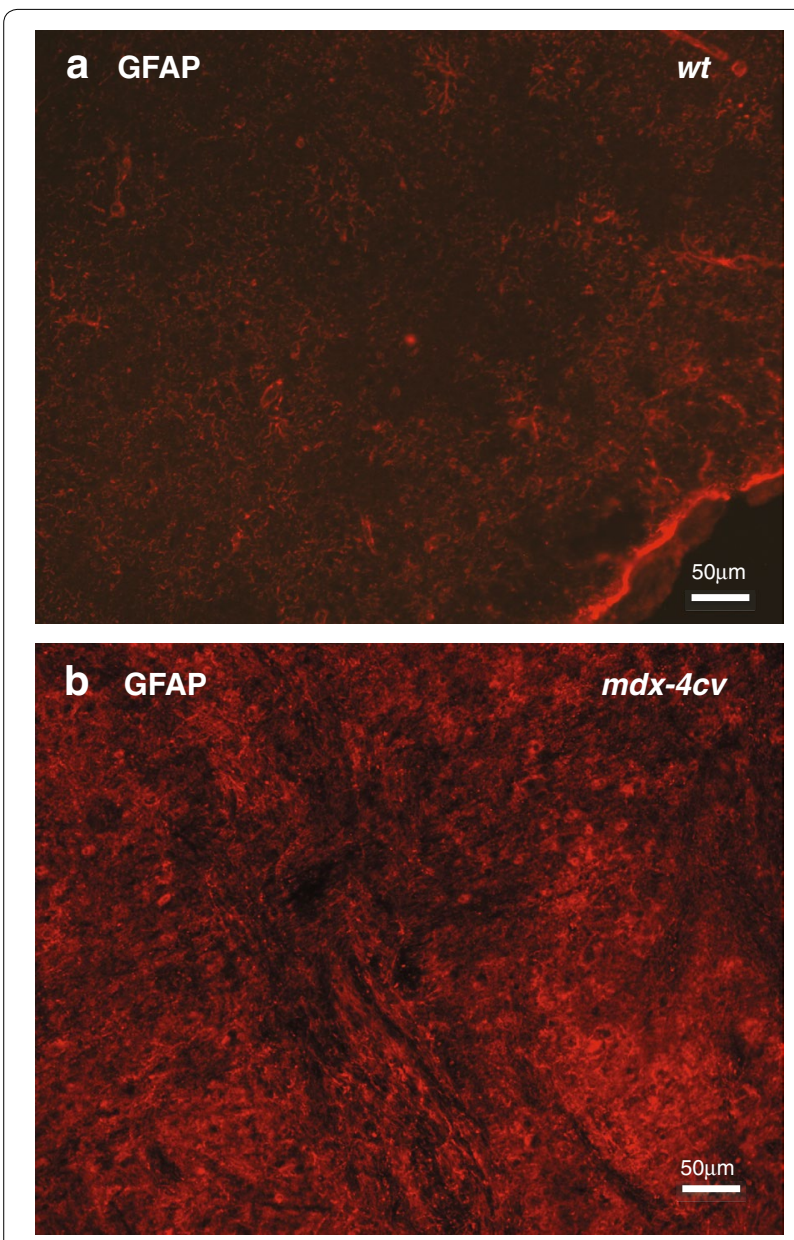

Fig. 6 Immunofluorescence microscopical analysis of the glial fibrillary acidic protein in normal versus $m d x-4 c v$ brain. Shown is the immunofluorescence labelling of brain sections using an antibody to glial fibrillary acidic protein (GFAP) in wild type a versus $m d x-4 c v$ b cortex. The $m d x-4 c v$ cortex exhibited a substantially higher level of GFAP labelling, which agrees with the findings from the mass spectrometric analysis and immunoblotting of the $m d x-4 c v$ brain. Bar equals $50 \mu \mathrm{m}$

[80], the up-regulation of annexin probably represents a subcellular repair mechanism involved in membrane maintenance [81] and elevated vimentin levels could function as cytoskeletal stabilization in the absence of brain dystrophin. Alternatively, vimentin changes may be linked to astrogliosis-related alterations in the intermediate filament system. Astrocyte activation and reactive gliosis in the damaged central nervous system has previously shown to be associated with the increased production of cytoskeletal proteins and rearrangements within the intermediate filament system of astrocytes [82].

In addition, the proteomic profiling of the $m d x-4 c v$ brain indicated metabolic adaptations, disturbed ion handling and functional changes in the central nervous system from the dystrophic phenotype. The immunoblotting analysis of the plasma membrane $\mathrm{Ca}^{2+}$-transporting ATPase 2 (Fig. 7d, h), which is mainly expressed in brain cortex, confirmed the proteomic identification of significantly reduced PMCA2 levels (Table 1). The $\mathrm{Ca}^{2+}$-pump activities of PMCA2 complexes are critical regulators of dendritic ion homeostasis that controls Purkinje cell dendritic growth [83]. In contrast to PMCA2, the $\mathrm{Ca}^{2+}$-binding protein calretinin [84] was shown to be significantly increased in the $m d x$-4cv brain (Table 1), possibly compensating abnormal calcium fluxes within specific neurons of the central nervous system. Interesting proteomic biomarker candidates with a differential expression pattern are the neuron-specific enzyme ubiquitin carboxyl-terminal hydrolase isozyme L1, the dendritic spine protein drebrin, the cytomatrix protein bassoon of the nerve terminal active zone, and the synapse-associated protein SAP97, as well as the nervous system-specific proteins syntaxin-1B and syntaxin-binding protein 1 [85].

\section{Conclusions}

The comparative proteomic profiling of wild type versus $m d x-4 c v$ brain extracts has resulted in the biochemical identification of a large number of proteins with a changed concentration. These novel proteomic candidates can now be evaluated for their suitability to establish a robust biomarker signature of brain pathology in Duchenne muscular dystrophy. In the future, brainassociated or brain-released protein biomarkers might be useful as predictive, diagnostic, prognostic and/or therapy-monitoring detection tools for the swift evaluation of brain abnormalities in dystrophinopathies. The scale of proteome-wide changes described in this report suggests complex molecular and cellular changes in the $m d x-4 c v$ brain that appear to be linked to both progressive neuron degeneration and reactive gliosis. Of special interest is the proteomic identification of the glial fibrillary acidic protein GFAP, which presents a major intermediate filament protein of mature astrocytes and an established biomarker of astrogliosis. Hence, its significant increase in the $m d x-4 c v$ brain agrees with the histopathological concept of reactive gliosis in the Dp427-deficient central nervous system. In addition, the up-regulation of the annexin isoform AnxA5 and vimentin suggest compensatory mechanisms at the level of plasma membrane repair mechanisms and cytoskeletal re-stabilization. Disturbed neuronal proteins involved in $\mathrm{Ca}^{2+}$-handling, metabolism and signalling in the central nervous system illustrate the complexity of the molecular pathogenesis in the dystrophic phenotype. 


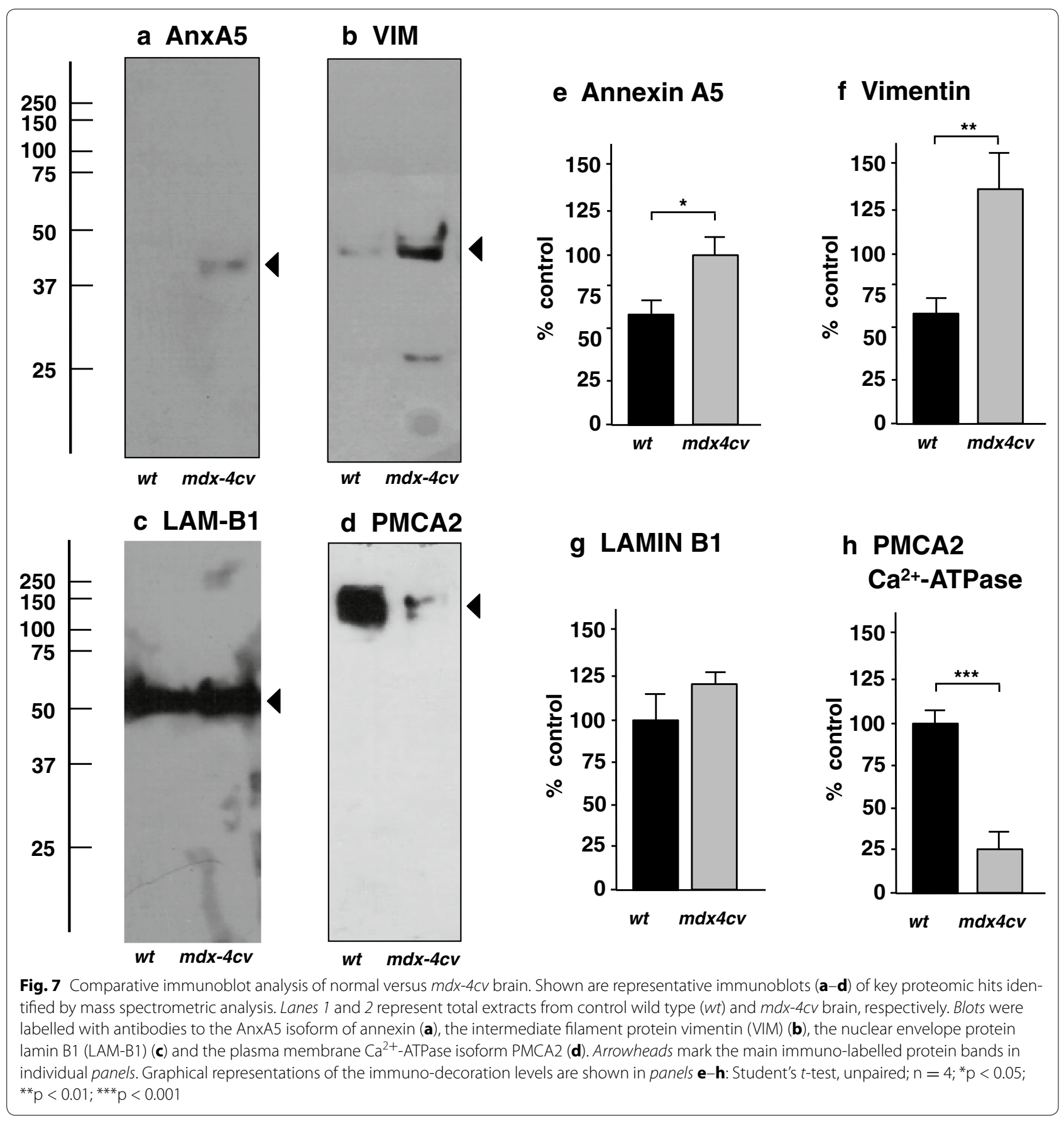

\section{Methods}

\section{Materials}

Whole tissue proteomics for the comparative profiling of $m d x-4 c v$ versus wild type brain was conducted using analytical grade reagents and materials obtained from GE Healthcare (Little Chalfont, Buckinghamshire, UK) and Bio-Rad Laboratories (Hemel-Hempstead, Hertfordshire, UK). A number of other chemicals were used in this mass spectrometry-based survey, including ultrapure acrylamide stock solutions which were purchased from National Diagnostics (Atlanta, GA, USA), sequencing grade modified trypsin and Lys-C obtained from Promega (Madison, WI, USA) and Whatman nitrocellulose transfer membranes from Invitrogen (Carlsbad, CA, USA). The chemiluminescence substrate and protease inhibitors were purchased from Roche 
Diagnostics (Mannheim, Germany). Superfrost Plus positively-charged microscope slides were from Menzel Glaesser (Braunschweig, Germany). Primary antibodies were purchased from Abcam, Cambridge, UK (ab14196 to annexin Anx5; ab7260 to glial fibrillary acidic protein GFAP; ab16048 to lamin-B1; ab3529 to the $\mathrm{Ca}^{2+}$-ATPase PMCA2; and ab52488 to lactate dehydrogenase) and Dako (Agilent Technologies), Hamburg, Germany (Rabbit polyclonal antibodies Z033429 to glial fibrillary acidic protein GFAP and A0082 to von Willebrand factor vWF). Chemicon International (Temecula, CA, USA) provided peroxidase-conjugated secondary antibodies. Normal goat serum and Cy3-conjugated goat anti-rabbit antibodies were from Jackson ImmunoResearch (West Grove, PA, USA). A range of other general chemicals were used, all of which were analytical grade and were obtained from Sigma Chemical Company (Dorset, UK).

\section{Dystrophic $m d x-4 c v$ mouse model of X-linked dystrophinopathy}

A deeper understanding of the pathobiochemistry of Duchenne muscular dystrophy has been greatly enhanced by the systematic proteomic profiling of established animal models [54]. The conventionally used $m d x$ mouse [86] in particular has been extensively used [87]. This genetic model, in analogy to the human condition, is almost completely lacking the full-length Dp427 isoform of dystrophin. Behavioural studies have shown significant differences in the retention of the passive avoidance response [48], long delays in spontaneous alternation and bar-pressing tasks [49] and impaired long-term spatial and recognition memory [50] in the $m d x$ mouse. The impairment in passive avoidance learning and behavioural changes in $m d x$ mice indicates that the loss of brain dystrophin is associated with cognitive dysfunctions. In relation to behavioural/neurological aspects of the $m d x-4 c v$ strain, the Mouse Genome Information site from Jackson Laboratory states that this dystrophic mouse model exhibits abnormal grip strength and that the determined grip strength is weaker than that of wild type and the $m d x-3 c v$ mouse (http://www.informatics. jax.org). This analysis indicates that muscular weakness and potentially behavioural deficits exist in the $m d x-4 c v$ mouse model of Duchenne muscular dystrophy. Importantly, the $m d x-4 c v$ mouse [88] displays ten-fold fewer revertant dystrophin-positive fibres [89] and immunoblotting has shown the absence of the shorter Dp140 and Dp260 isoforms, as well as the full-length brain, Purkinje and muscle Dp427 isoforms [90]. This renders the $m d x$ $4 c v$ mouse a more suitable model system for the study of new therapeutic avenues, such as exon skipping or stopcodon read-through therapy [91]. In order to investigate the effect of Dp427 deficiency on protein expression patterns in the central nervous system, whole brains were removed from 2-, 8- and 12-month old $m d x-4 c v$ mice and aged-matched control C57BL6 mice. All animals used in this study were housed at the Bioresource Unit at the University of Bonn [92], where they were kept under standard conditions according to German and Irish legislation on the use of animals in experimental research. The animals were sacrificed by cervical dislocation and all tissue samples were immediately isolated [93].

\section{Preparation of tissue extracts from $m d x-4 c v$ and wild type brain for proteomic analysis}

Brain samples from 12-month old wild type $(w t)(\mathrm{n}=4)$ and $m d x-4 c v(\mathrm{n}=4)$ animals were freshly dissected, quick-frozen in liquid-nitrogen and stored at $-80{ }^{\circ} \mathrm{C}$ prior to usage. Freshly thawed brain tissue $(100 \mathrm{mg})$ was finely chopped and homogenised in 10 volumes of homogenisation buffer ( $8 \mathrm{M}$ urea, $50 \mathrm{mM}$ Tris- $\mathrm{HCl}$ pH 8.0, 1 mM EDTA) using a hand-held IKA T10 Basic Homogeniser (IKA Labortechnik, Staufen, Germany). To limit potential protein degradation by protease activity, this buffer was supplemented with a protease inhibitor cocktail from Roche Diagnostics (Mannheim, Germany). Brain homogenates were incubated at $4{ }^{\circ} \mathrm{C}$ for $1.5 \mathrm{~h}$ with gentle shaking using a Thermomixer from Eppendorf (Hamburg, Germany). Samples were centrifuged at $14,000 \times g$ for $20 \mathrm{~min}$ at $4{ }^{\circ} \mathrm{C}$, and the urea-soluble protein-containing middle layer was isolated for proteomic analysis [94].

\section{Preparation of tissue extracts from liver, diaphragm, leg muscle, heart and brain}

In order to investigate the tissue-specificity of the antibody to GFAP, comparative immunoblotting was employed. For this purpose a variety of mouse tissue types were used, including liver, heart, hind limb skeletal muscles, diaphragm and brain. All samples were from control wild type mice. For the preparation of total extracts from liver, skeletal muscle and diaphragm, $50 \mathrm{mg}$ of tissue samples were finely chopped and homogenised in $0.5 \mathrm{ml}$ of homogenisation buffer $(20 \mathrm{mM}$ sodium pyrophosphate, $20 \mathrm{mM}$ sodium phosphate, $1 \mathrm{mM} \mathrm{MgCl}{ }_{2}$, $0.303 \mathrm{M}$ sucrose, $0.5 \mathrm{mM}$ EDTA, $\mathrm{pH}$ 7.0), using a handheld IKA T10 Basic Homogeniser (IKA Labortechnik, Staufen, Germany) [93]. Similarly, $50 \mathrm{mg}$ of heart and brain samples were finely chopped and homogenised in lysis buffer (7 M urea, $2 \mathrm{M}$ thiourea, $4 \%$ CHAPS, 2 \% DTT, 2 \% IPG buffer pH 3-10) and homogenisation buffer (8 M urea, $50 \mathrm{mM}$ Tris- $\mathrm{HCl} \mathrm{pH} 8.0,1 \mathrm{mM}$ EDTA), respectively [94]. All buffers were supplemented with a protease inhibitor cocktail from Roche Diagnostics (Mannheim, Germany) to minimise protein degradation. Protein extracts were gently shaken at $4{ }^{\circ} \mathrm{C}$ for 
$1.5 \mathrm{~h}$ using a Thermomixer from Eppendorf (Hamburg, Germany). Following centrifugation at $14,000 \mathrm{~g}$ for $20 \mathrm{~min}$ at $4{ }^{\circ} \mathrm{C}$, the supernatant fractions were isolated and the protein concentrations were determined by the method of Bradford [95]. Samples were then used for comparative immunoblotting.

\section{Sample preparation for label-free liquid chromatography mass spectrometry}

Prior to mass spectrometric analysis, protein samples were pre-treated with the Ready Prep 2D clean up kit from Bio-Rad Laboratories (Hemel-Hempstead, Hertfordshire, UK). This removed contaminating agents, which may otherwise interfere with the mass spectrometric analysis. The pellets obtained from this procedure were resuspended in label-free solubilisation buffer (6 M urea, $2 \mathrm{M}$ thiourea, $10 \mathrm{mM}$ Tris, $\mathrm{pH} 8.0$ in LC-MS grade water), and samples were vortexed and sonicated to aid full resuspension [93]. Protein concentrations were determined by the method of Bradford [95] and sample volumes were equalised with label-free solubilisation buffer. Samples were treated with $10 \mathrm{mM}$ DTT for $30 \mathrm{~min}$ at $37{ }^{\circ} \mathrm{C}$ as a means of reducing protein disulphide bonds. Cysteine residues were alkylated by adding iodoacetamide to a concentration of $25 \mathrm{mM}$ in $50 \mathrm{mM}$ ammonium bicarbonate and incubating for $20 \mathrm{~min}$ in the dark. To limit the possibility of trypsin alkylation by unreacted iodoacetamide, samples were further reduced with $10 \mathrm{mM}$ dithiothreitol for $15 \mathrm{~min}$ in the dark. Protein digestion was carried out in two steps. Firstly proteolytic digestion was carried out with sequencing grade Lys-C at a ratio of $1: 100$ (protease:protein) at $37^{\circ} \mathrm{C}$ for $4 \mathrm{~h}$ with agitation. Following the initial cleavage of peptide bonds, samples were diluted with four times the initial sample volume in $50 \mathrm{mM}$ ammonium bicarbonate. The final stage of protein digestion was achieved by incubation with sequencing grade trypsin overnight at $37^{\circ} \mathrm{C}$ at a ratio of 1:25 (protease:protein). Acidification with $2 \%$ trifluoroacetic acid (TFA) in $20 \%$ acetonitrile (ACN) [3:1 (v/v) dilution] terminated protein digestion. The sample digests were purified with Pierce C18 Spin Columns from Thermo Fisher Scientific (Dublin, Ireland), dried through vacuum centrifugation and resuspended in loading buffer consisting of $2 \% \mathrm{ACN}$ and $0.05 \%$ TFA in LC-MS grade water. To ensure the even suspension of peptides, samples were vortexed and sonicated prior to loading on the mass spectrometer.

\section{Label-free liquid-chromatography mass spectrometric analysis}

The nano LC-MS/MS analysis of $m d x-4 c v$ versus $w t$ brain tissue was carried out with an Ultimate 3000 nanoLC system (Dionex) coupled to an LTQ Orbitrap
XL mass spectrometer (Thermo Fisher Scientific) in the Proteomics Facility of the National Institute for Cellular Biotechnology, Dublin City University, using optimised methodology [96]. Digested peptide samples (5 $\mu \mathrm{l}$ volume) were loaded onto a C18 trap column (C18 PepMap, $300 \mu \mathrm{m}$ id $\times 5 \mathrm{~mm}, 5 \mu \mathrm{m}$ particle size, $100 \AA$ pore size; Dionex). Desalting was performed at a flow rate of $25 \mu \mathrm{l} /$ min in $0.1 \% \mathrm{TFA} / 2 \% \mathrm{ACN}$ for $10 \mathrm{~min}$. The trap column was then switched on-line with an analytical PepMap C18 column $(75 \mu \mathrm{m}$ id $\times 500 \mathrm{~mm}, 3 \mu \mathrm{m}$ particle and 100 $\AA$ pore size; Dionex). Brain-tissue derived peptides were eluted with the following binary gradients: solvent A [2\% (v/v) ACN (acetonitrile) and $0.1 \%(\mathrm{v} / \mathrm{v})$ formic acid in LC-MS grade water] and 0-25\% solvent B [80\% ACN and $0.08 \%(\mathrm{v} / \mathrm{v})$ formic acid in LC-MS grade water] for $240 \mathrm{~min}$ and $25-50 \%$ solvent B for a further $60 \mathrm{~min}$, with a column flow rate set to $350 \mathrm{nl} / \mathrm{min}$ [86]. Data were acquired with Xcalibur software, version 2.0.7 (Thermo Fisher Scientific). The MS apparatus was operated in positive, data-dependent mode and was externally calibrated. Survey MS scans were attained in the 400-1200 $m / z$ range with the resolution set to a value of 30,000 at $\mathrm{m} / \mathrm{z} 400$ and lock mass set to $445.120025 \mathrm{u}$. Collisioninduced dissociation (CID) fragmentation was carried out with the three most intense ions per scan. A dynamic exclusion window was applied within $60 \mathrm{~s}$ [97]. A normalized collision energy of $35 \%$, an isolation window of 3 $\mathrm{m} / \mathrm{z}$ and one microscan were used to collect suitable tandem mass spectra.

\section{Quantitative mass spectrometric identification of brain-derived proteins}

The raw data obtained from the LC-MS/MS analysis was processed using Progenesis QI for Proteomics software (version 2.0; Non-Linear Dynamics, a Waters company, Newcastle upon Tyne, UK). Crucially the LC retention times of all data were aligned to an assigned reference run (run with the most peptides), to allow for any drift in retention time [95]. Prior to exportation to Proteome Discoverer 1.4 (Thermo Scientific), the MS/MS data files were filtered using the following parameters; (1) peptide features with ANOVA $\leq 0.05$ between experimental groups, (2) mass peaks with charge states from +1 to +5 and (3) greater than one isotope per peptide. The PepXML generic file, generated from all exported MS/ MS spectra, was used for peptide identification using Proteome Discoverer 1.4 against Mascot (version 2.3, Matrix Science, Boston, MA, USA) and Sequest HT (SEQUEST HT algorithm, licence Thermo Scientific, registered trademark University of Washington, USA) and searched against the UniProtKB-SwissProt database (taxonomy: Mus musculus). The following search parameters were used for protein identification: (1) peptide mass 
tolerance set to $20 \mathrm{ppm}$, (2) MS/MS mass tolerance set to $0.6 \mathrm{Da}$, (3) up to two missed cleavages were allowed, (4) carbamidomethylation set as a fixed modification and (5) methionine oxidation set as a variable modification [97]. For re-importation back into Progenesis LC-MS software for further analysis, only peptides with either ion scores of 40.00 or more (from Mascot) and peptides with XCorr scores $>1.9$ for singly charged ions, $>2.2$ for doubly charged ions and $>3.75$ for triply charged ions or more (from Sequest HT) were selected. A number of criteria were applied to ensure proper identification of brain-tissue derived proteins, including an ANOVA score between experimental groups of $\leq 0.05$ and proteins with $\geq 2$ peptides matched.

\section{Bioinformatics analysis of potential protein interactions}

The freely available software package PANTHER (http:// pantherdb.org) was used for the bioinformatics analysis of the mass spectrometric findings generated in this study [68]. Proteins with an altered expression in $m d x$ $4 c v$ brain samples were grouped based on their protein class using the PANTHER database of protein families.

\section{Independent verification of key proteomic hits by immunoblot analysis}

In order to confirm alterations in protein expression, as identified by label-free mass spectrometry, immunoblot analysis using a panel of antibodies against select proteins was employed. Electrophoretic separation of proteins from 2-, 8- and 12-month old wild type and $m d x-4 c v$ brain tissues, as well as extracts from liver, heart, diaphragm and leg muscles, was performed using standard $10 \%$ polyacrylamide gels, followed by wet transfer at $100 \mathrm{~V}$ for $70 \mathrm{~min}$ at $4{ }^{\circ} \mathrm{C}$ to Whatman Protan nitrocellulose sheets in a Transblot Cell from Bio-Rad Laboratories (Hemel-Hempstead, Hertfordshire, UK) as per standard procedure [98]. Membranes were blocked for $1 \mathrm{~h}$ at room temperature with a milk protein solution [2.5\% (w/v) fat-free milk powder in $10 \%$ phosphate-buffered saline] prior to incubation with primary antibodies to limit non-specific binding. Nitrocellulose sheets were then incubated with sufficiently diluted primary antibodies overnight at $4{ }^{\circ} \mathrm{C}$ with gentle agitation. Membranes were subsequently washed twice with the milk protein solution for $10 \mathrm{~min}$ each time, followed by incubation for $1.5 \mathrm{~h}$ with peroxidase-conjugated secondary antibodies, diluted in the blocking buffer. Visualisation of antibody-labelled protein bands on washed membranes was achieved using enhanced chemiluminescence as per manufacturer's guidelines. Densitometric scanning and statistical analysis of immunoblots was performed with a HP PSC-2355 scanner and ImageJ software (NIH, USA), in conjunction with GraphPad Prism software (San Diego, CA, USA), in which a $p$ value $<0.05$ was deemed to be statistically significant.

\section{Immunofluorescence microscopy of brain sections}

In order to verify the increased abundance of the glial fibrillary acidic protein (GFAP) in the Dp427-deficient brain, as well as study vascularization by labelling brain tissue with von Willebrand factor (vWF), $m d x$ $4 c v$ versus wild type cortex sections were analysed by immunofluorescence microscopy [32]. Brains were carefully removed and quick-frozen in liquid nitrogen. Cryo-sectioning was used to produce $10 \mu \mathrm{m}$ sagittal sections, which were placed on Superfrost Plus positively-charged microscope slides. Brain sections were fixed for $5 \mathrm{~min}$ in ice-cold $4 \%(\mathrm{v} / \mathrm{v})$ paraformaldehyde in phosphate-buffered saline (PBS). Sections were then permeabilized in $0.1 \%(\mathrm{v} / \mathrm{v})$ Triton X-100 in PBS for $30 \mathrm{~min}$ at room temperature. Tissue sections were blocked in $20 \%(\mathrm{v} / \mathrm{v})$ normal goat serum in PBS for 30 min and incubated overnight at $4{ }^{\circ} \mathrm{C}$ with rabbit polyclonal antibodies to GFAP (1:300 in PBS) or vWF (1:400 in PBS). Following a careful washing step, brain sections were incubated with Cy3-conjugated anti-rabbit antibodies (1:300) for $30 \mathrm{~min}$ at room temperature. Primary antibodies were omitted for control staining. Antibodylabelled brain sections were embedded in Fluoromount G medium and viewed under a Zeiss Axioskop 2 epifluorescence microscope equipped with a digital Zeiss AxioCam HRc camera (Carl Zeiss Jena GmbH, Jena, Germany).

\section{Authors' contributions}

SM designed and performed the main analytical experiments of the analysis of the $m d x-4 c v$ brain. DS and $\mathrm{KO}$ conceived this collaborative study and provided scientific oversight. MZ and RM were involved in the maintenance of the mouse colonies, performed the preparation of tissue samples and carried out the immunofluorescence microscopical analyses. MH and PM provided the detailed analysis of mass spectrometric data. All authors were involved in interpreting of data, as well as the writing and correcting of the manuscript. All authors read and approved the final manuscript.

\section{Author details}

${ }^{1}$ Department of Biology, Maynooth University, National University of Ireland, Maynooth, Co. Kildare, Ireland. ${ }^{2}$ Department of Physiology II, University of Bonn, 53115 Bonn, Germany. ${ }^{3}$ National Institute for Cellular Biotechnology, Dublin City University, Dublin 9, Ireland.

\section{Acknowledgements}

Research was supported by a Hume scholarship from Maynooth University and project grants from the Deutsche Duchenne Stiftung aktion benni \& co e.V. and Muscular Dystrophy Ireland.

\section{Competing interests}

The authors declare that they have no competing interests.

Received: 4 September 2015 Accepted: 13 November 2015

Published online: 23 November 2015 


\section{References}

1. Hunsucker SW, Accurso FJ, Duncan MW. Proteomics in pediatric research and practice. Adv Pediatr. 2007;54:9-28.

2. Savage WJ, Everett AD. Biomarkers in pediatrics: children as biomarker orphans. Proteom Clin Appl. 2010;4:915-21.

3. Young J, Stone WL. Pediatric proteomics: an introduction. Front Biosci. 2012;4:1078-87

4. Emery AE. The muscular dystrophies. Lancet. 2002;359:687-95.

5. Chelly J, Desguerre I. Progressive muscular dystrophies. Handb Clin Neurol. 2013;113:1343-66.

6. Flanigan KM. Duchenne and Becker muscular dystrophies. Neurol Clin. 2014;32:671-88.

7. Hoffman EP, Brown RH Jr, Kunkel LM. Dystrophin: the protein product of the Duchenne muscular dystrophy locus. Cell. 1987;51:919-28.

8. Ervasti JM, Ohlendieck K, Kahl SD, Gaver MG, Campbell KP. Deficiency of a glycoprotein component of the dystrophin complex in dystrophic muscle. Nature. 1990;345:315-9.

9. Ohlendieck K, Matsumura K, lonasescu W, Towbin JA, Bosch EP, Weinstein SL, Sernett SW, Campbell KP. Duchenne muscular dystrophy: deficiency of dystrophin-associated proteins in the sarcolemma. Neurology. 1993;43:795-800.

10. Ohlendieck K. Towards an understanding of the dystrophin-glycoprotein complex: linkage between the extracellular matrix and the membrane cytoskeleton in muscle fibers. Eur J Cell Biol. 1996;69:1-10.

11. Connuck DM, Sleeper LA, Colan SD, Cox GF, Towbin JA, Lowe AM, Wilkinson JD, Orav EJ, Cuniberti L, Salbert BA, Lipshultz SE, Pediatric Cardiomyopathy Registry Study Group. Characteristics and outcomes of cardiomyopathy in children with Duchenne or Becker muscular dystrophy: a comparative study from the Pediatric Cardiomyopathy Registry. Am Heart J. 2008;155:998-1005.

12. Hsu JD, Quinlivan R. Scoliosis in Duchenne muscular dystrophy (DMD). Neuromuscul Disord. 2013;23:611-7.

13. Klingler W, Jurkat-Rott K, Lehmann-Horn F, Schleip R. The role of fibrosis in Duchenne muscular dystrophy. Acta Myol. 2012;31:184-95.

14. Khirani S, Ramirez A, Aubertin G, Boulé M, Chemouny C, Forin V, Fauroux B. Respiratory muscle decline in Duchenne muscular dystrophy. Pediatr Pulmonol. 2014:49:473-81.

15. Bushby K, Finkel R, Birnkrant DJ, Case LE, Clemens PR, Cripe L, Kaul A, Kinnett K, McDonald C, Pandya S, Poysky J, Shapiro F, Tomezsko J, Constantin C, DMD Care Considerations Working Group. Diagnosis and management of Duchenne muscular dystrophy, part 1: diagnosis, and pharmacological and psychosocial management. Lancet Neurol. 2010;9:77-93.

16. Bushby K, Finkel R, Birnkrant DJ, Case LE, Clemens PR, Cripe L, Kaul A, Kinnett K, McDonald C, Pandya S, Poysky J, Shapiro F, Tomezsko J, Constantin C, DMD Care Considerations Working Group. Diagnosis and management of Duchenne muscular dystrophy, part 2: implementation of multidisciplinary care. Lancet Neurol. 2010;9:177-89.

17. Goemans N, Buyse G. Current treatment and management of dystrophinopathies. Curr Treat Options Neurol. 2014;16:287.

18. Muntoni F, Torelli S, Ferlini A. Dystrophin and mutations: one gene, several proteins, multiple phenotypes. Lancet Neurol. 2003;2:731-40.

19. Culligan K, Ohlendieck K. Diversity of the brain dystrophin-glycoprotein complex. J Biomed Biotechnol. 2002;2:31-6.

20. Waite A, Tinsley CL, Locke M, Blake DJ. The neurobiology of the dystrophin-associated glycoprotein complex. Ann Med. 2009;41:344-59.

21. Perronnet C, Vaillend C. Dystrophins, utrophins, and associated scaffolding complexes: role in mammalian brain and implications for therapeutic strategies. J Biomed Biotechnol. 2010;2010:849426.

22. Hendriksen RG, Hoogland G, Schipper S, Hendriksen JG, Vles JS, Aalbers MW. A possible role of dystrophin in neuronal excitability: a review of the current literature. Neurosci Biobehav Rev. 2015;51:255-62.

23. Waite A, Brown SC, Blake DJ. The dystrophin-glycoprotein complex in brain development and disease. Trends Neurosci. 2012;35:487-96.

24. Lidov HG, Byers TJ, Kunkel LM. The distribution of dystrophin in the murine central nervous system: an immunocytochemical study. Neuroscience. 1993;54:167-87.

25. Kim TW, Wu K, Xu JL, Black IB. Detection of dystrophin in the postsynaptic density of rat brain and deficiency in a mouse model of Duchenne muscular dystrophy. Proc Natl Acad Sci USA. 1992;89:11642-4.

26. Kim TW, Wu K, Black IB. Deficiency of brain synaptic dystrophin in human Duchenne muscular dystrophy. Ann Neurol. 1995;38:446-9.
27. Uchino M, Hara A, Mizuno Y, Fujiki M, Nakamura T, Tokunaga M, Hirano T, Yamashita T, Uyama E, Ando Y, Mita S, Ando M. Distribution of dystrophin and dystrophin-associated protein 43DAG (beta-dystroglycan) in the central nervous system of normal controls and patients with Duchenne muscular dystrophy. Intern Med. 1996;35:189-94.

28. Finn DM, Ohlendieck K. Oligomerization of beta-dystroglycan in rabbit diaphragm and brain as revealed by chemical crosslinking. Biochim Biophys Acta. 1998;1370:325-36.

29. Finn DM, Ohlendieck K. Rabbit brain and muscle isoforms containing the carboxy-terminal domain of 427 kDa skeletal muscle dystrophin exhibit similar biochemical properties. Neurosci Lett. 1997;222:25-8.

30. Lidov HG, Selig S, Kunkel LM. Dp140: a novel 140 kDa CNS transcript from the dystrophin locus. Hum Mol Genet. 1995;4:329-35.

31. Blake DJ, Love DR, Tinsley J, Morris GE, Turley H, Gatter K, Dickson G, Edwards YH, Davies KE. Characterization of a 4.8 kb transcript from the Duchenne muscular dystrophy locus expressed in Schwannoma cells. Hum Mol Genet. 1992;1:103-9.

32. Culligan K, Glover L, Dowling P, Ohlendieck K. Brain dystrophin-glycoprotein complex: persistent expression of beta-dystroglycan, impaired oligomerization of Dp71 and up-regulation of utrophins in animal models of muscular dystrophy. BMC Cell Biol. 2001;2:2.

33. Tadayoni R, Rendon A, Soria-Jasso LE, Cisneros B. Dystrophin Dp71: the smallest but multifunctional product of the Duchenne muscular dystrophy gene. Mol Neurobiol. 2012;45:43-60.

34. Kozicka A, Prot J, Wasilewski R. Mental retardation in patients with Duchenne progressive muscular dystrophy. J Neurol Sci. 1971;14:209-13.

35. Marsh GG, Munsat TL. Evidence of early impairment of verbal intelligence in Duchenne muscular dystrophy. Arch Dis Child. 1974;49:118-22.

36. Karagan NJ. Intellectual functioning in Duchenne muscular dystrophy: a review. Psychol Bull. 1979;86:250-9.

37. Leibowitz D, Dubowitz V. Intellect and behaviour in Duchenne muscular dystrophy. Dev Med Child Neurol. 1981;23:577-90.

38. Fitzpatrick C, Barry C, Garvey C. Psychiatric disorder among boys with Duchenne muscular dystrophy. Dev Med Child Neurol. 1986;28:589-95.

39. Ogasawara A. Downward shift in $I Q$ in persons with Duchenne muscular dystrophy compared to those with spinal muscular atrophy. Am J Ment Retard. 1989;93:544-7.

40. Smith RA, Sibert JR, Harper PS. Early development of boys with Duchenne muscular dystrophy. Dev Med Child Neurol. 1990;32:519-27.

41. Yoshioka M, Okuno T, Honda Y, Nakano Y. Central nervous system involvement in progressive muscular dystrophy. Arch Dis Child. 1980;55:589-94.

42. Bresolin N, Castelli E, Comi GP, Felisari G, Bardoni A, Perani D, Grassi F, Turconi A, Mazzucchelli F, Gallotti D, et al. Cognitive impairment in Duchenne muscular dystrophy. Neuromuscul Disord. 1994;4:359-69.

43. Felisari G, Martinelli Boneschi F, Bardoni A, Sironi M, Comi GP, Robotti M, Turconi AC, Lai M, Corrao G, Bresolin N. Loss of Dp140 dystrophin isoform and intellectual impairment in Duchenne dystrophy. Neurology. 2000;55:559-64.

44. Bardoni A, Felisari G, Sironi M, Comi G, Lai M, Robotti M, Bresolin N. Loss of Dp140 regulatory sequences is associated with cognitive impairment in dystrophinopathies. Neuromuscul Disord. 2000;10:194-9.

45. Mehler MF. Brain dystrophin, neurogenetics and mental retardation. Brain Res Brain Res Rev. 2000;32:277-307.

46. Anderson JL, Head SI, Rae C, Morley JW. Brain function in Duchenne muscular dystrophy. Brain. 2002;125:4-13.

47. Snow WM, Anderson JE, Jakobson LS. Neuropsychological and neurobehavioral functioning in Duchenne muscular dystrophy: a review. Neurosci Biobehav Rev. 2013;37:743-52.

48. Muntoni F, Mateddu A, Serra G. Passive avoidance behaviour deficit in the mdx mouse. Neuromuscul Disord. 1991;1:121-3.

49. Vaillend C, Rendon A, Misslin R, Ungerer A. Influence of dystrophingene mutation on mdx mouse behavior. I. Retention deficits at long delays in spontaneous alternation and bar-pressing tasks. Behav Genet. 1995;25:569-79.

50. Vaillend C, Billard JM, Laroche S. Impaired long-term spatial and recognition memory and enhanced CA1 hippocampal LTP in the dystrophindeficient Dmd(mdx) mouse. Neurobiol Dis. 2004;17:10-20.

51. Tracey I, Dunn JF, Radda GK. Brain metabolism is abnormal in the mdx model of Duchenne muscular dystrophy. Brain. 1996;119:1039-44.

52. Mehler MF, Haas KZ, Kessler JA, Stanton PK. Enhanced sensitivity of hippocampal pyramidal neurons from mdx mice to hypoxia-induced loss of synaptic transmission. Proc Natl Acad Sci USA. 1992;89:2461-5. 
53. Kueh SL, Dempster J, Head SI, Morley JW. Reduced postsynaptic GABAA receptor number and enhanced gaboxadol induced change in holding currents in Purkinje cells of the dystrophin-deficient mdx mouse. Neurobiol Dis. 2011:43:558-64.

54. Holland A, Carberry S, Ohlendieck K. Proteomics of the dystrophinglycoprotein complex and dystrophinopathy. Curr Protein Pept Sci. 2013;14:680-97

55. Korshunova I, Caroni P, Kolkova K, Berezin V, Bock E, Walmod PS. Characterization of BASP1-mediated neurite outgrowth. J Neurosci Res. 2008;86:2201-13.

56. Oyler GA, Higgins GA, Hart RA, Battenberg E, Billingsley M, Bloom FE, Wilson MC. The identification of a novel synaptosomal-associated protein, SNAP-25, differentially expressed by neuronal subpopulations. J Cell Biol. 1989;109:3039-52.

57. Favre B, Schneider Y, Lingasamy P, Bouameur JE, Begré N, Gontier $Y$, Steiner-Champliaud MF, Frias MA, Borradori L, Fontao L. Plectin interacts with the rod domain of type III intermediate filament proteins desmin and vimentin. Eur J Cell Biol. 2011;90:390-400.

58. Therien AG, Blostein R. Mechanisms of sodium pump regulation. Am J Physiol Cell Physiol. 2000;279:C541-66

59. Wagner DD, Olmsted JB, Marder VJ. Immunolocalization of von Willebrand protein in Weibel-Palade bodies of human endothelial cells. J Cell Biol. 1982;95(1):355-60.

60. Lenting PJ, Casari C, Christophe OD, Denis CV. von Willebrand factor: the old, the new and the unknown. J Thromb Haemost. 2012;10:2428-37.

61. Rondaij MG, Bierings $R$, Kragt A, van Mourik JA, Voorberg J. Dynamics and plasticity of Weibel-Palade bodies in endothelial cells. Arterioscler Thromb Vasc Biol. 2006;26:1002-7

62. Nico B, Frigeri A, Nicchia GP, Corsi P, Ribatti D, Quondamatteo F, Herken R, Girolamo F, Marzullo A, Svelto M, Roncali L. Severe alterations of endothelial and glial cells in the blood-brain barrier of dystrophic mdx mice. Glia. 2003:42:235-51.

63. Adornato BT, Engel WK, Foidart-Desalle M. Elevations of hemopexin levels in neuromuscular disease. Arch Neurol. 1978;35:577-80.

64. Percy ME, Pichora GA, Chang LS, Manchester KE, Andrews DF. Serum myoglobin in Duchenne muscular dystrophy carrier detection: a comparison with creatine kinase and hemopexin using logistic discrimination. Am J Med Genet. 1984;18:279-87.

65. Wang J, Pantopoulos K. Regulation of cellular iron metabolism. Biochem J. 2011:434:365-81.

66. Miravitlles M. Alpha-1-antitrypsin and other proteinase inhibitors. Curr Opin Pharmacol. 2012;12:309-14.

67. Mori K, Emoto M, Inaba M. Fetuin-A: a multifunctional protein. Recent Pat Endocr Metab Immune Drug Discov. 2011;5:124-46.

68. Mi H, Muruganujan A, Thomas PD. PANTHER in 2013: modeling the evolution of gene function, and other gene attributes, in the context of phylogenetic trees. Nucleic Acids Res. 2013;41:D377-86.

69. Yang Z, Wang KK. Glial fibrillary acidic protein: from intermediate filament assembly and gliosis to neurobiomarker. Trends Neurosci. 2015;38:364-74.

70. Jha MK, Kim JH, Suk K. Proteome of brain glia: the molecular basis of diverse glial phenotypes. Proteomics. 2014;14:378-98.

71. Hol EM, Pekny M. Glial fibrillary acidic protein (GFAP) and the astrocyte intermediate filament system in diseases of the central nervous system. Curr Opin Cell Biol. 2015;32:121-30.

72. Kristjánsdóttir R, Uvebrant P, Rosengren L. Glial fibrillary acidic protein and neurofilament in children with cerebral white matter abnormalities. Neuropediatrics. 2001;32:307-12.

73. Tomassoni D, Avola R, Di Tullio MA, Sabbatini M, Vitaioli L, Amenta F. Increased expression of glial fibrillary acidic protein in the brain of spontaneously hypertensive rats. Clin Exp Hypertens. 2004;26:335-50.

74. Brenner M. Role of GFAP in CNS injuries. Neurosci Lett. 2014:565:7-13.

75. Singh A, Isaac AO, Luo X, Mohan ML, Cohen ML, Chen F, Kong Q, Bartz J, Singh N. Abnormal brain iron homeostasis in human and animal prion disorders. PLoS Pathog. 2009;5:e1000336.

76. Itoh K, Jinnai K, Tada K, Hara K, Itoh H, Takahashi H. Multifocal glial nodules in a case of Duchenne muscular dystrophy with severe mental retardation. Neuropathology. 1999;19:322-7.

77. Nico B, Paola Nicchia G, Frigeri A, Corsi P, Mangieri D, Ribatti D, Svelto M, Roncali L. Altered blood-brain barrier development in dystrophic MDX mice. Neuroscience. 2004:125:921-35.
78. Nico B, Corsi P, Ria R, Crivellato E, Vacca A, Roccaro AM, Mangieri D, Ribatti $D$, Roncali L. Increased matrix-metalloproteinase-2 and matrix-metalloproteinase-9 expression in the brain of dystrophic mdx mouse. Neuroscience. 2006;140:835-48.

79. Nico B, Tamma R, Annese T, Mangieri D, De Luca A, Corsi P, Benagiano V, Longo V, Crivellato E, Salmaggi A, Ribatti D. Glial dystrophin-associated proteins, laminin and agrin, are downregulated in the brain of $\mathrm{mdx}$ mouse. Lab Invest. 2010;90:1645-60.

80. Holland A, Henry M, Meleady P, Winkler CK, Krautwald M, Brinkmeier H, Ohlendieck K. Comparative label-free mass spectrometric analysis of mildly versus severely affected mdx mouse skeletal muscles identifies annexin, lamin, and vimentin as universal dystrophic markers. Molecules. 2015;20:11317-44.

81. Bouter A, Carmeille R, Gounou C, Bouvet F, Degrelle SA, Evain-Brion D, Brisson AR. Review: annexin-A5 and cell membrane repair. Placenta. 2015;36(Suppl 1):S43-9.

82. Pekny M, Wilhelmsson U, Pekna M. The dual role of astrocyte activation and reactive gliosis. Neurosci Lett. 2014;565:30-8.

83. Sherkhane P, Kapfhammer JP. The plasma membrane $\mathrm{Ca}^{2+}$-ATPase2 (PMCA2) is involved in the regulation of Purkinje cell dendritic growth in cerebellar organotypic slice cultures. Neural Plast. 2013;2013:321685.

84. Camp AJ, Wijesinghe R. Calretinin: modulator of neuronal excitability. Int J Biochem Cell Biol. 2009;41:2118-21.

85. Plum S, Steinbach S, Abel L, Marcus K, Helling S, May C. Proteomics in neurodegenerative diseases: methods for obtaining a closer look at the neuronal proteome. Proteom Clin Appl. 2015;9:848-71.

86. Partridge TA. The mdx mouse model as a surrogate for Duchenne muscular dystrophy. FEBS J. 2013;280:4177-86.

87. Dowling P, Holland A, Ohlendieck K. Mass spectrometry-based identification of muscle-associated and muscle-derived proteomic biomarkers of dystrophinopathies. J Neuromusc Dis. 2014;1:15-40.

88. Chapman VM, Miller DR, Armstrong D, Caskey CT. Recovery of induced mutations for $X$ chromosome-linked muscular dystrophy in mice. Proc Natl Acad Sci USA. 1989;86:1292-6.

89. Danko I, Chapman V, Wolff JA. The frequency of revertants in $\mathrm{mdx}$ mouse genetic models for Duchenne muscular dystrophy. Pediatr Res. 1992:32:128-31.

90. Im WB, Phelps SF, Copen EH, Adams EG, Slightom JL, Chamberlain JS. Differential expression of dystrophin isoforms in strains of $\mathrm{mdx}$ mice with different mutations. Hum Mol Genet. 1996:5:1149-53.

91. Mitrpan C, Fletcher S, Iversen PL, Wilton SD. By-passing the nonsense mutation in the $4 \mathrm{CV}$ mouse model of muscular dystrophy by induced exon skipping. J Gene Med. 2009;11:46-56.

92. Carberry S, Zweyer M, Swandulla D, Ohlendieck K. Comparative proteomic analysis of the contractile-protein-depleted fraction from normal versus dystrophic skeletal muscle. Anal Biochem. 2014;446:108-15.

93. Murphy S, Henry M, Meleady P, Zweyer M, Mundegar RR, Swandulla D, Ohlendieck K. Simultaneous pathoproteomic evaluation of the dystrophin-glycoprotein complex and secondary changes in the $\mathrm{mdx}-4 \mathrm{cv}$ of Duchenne muscular dystrophy. Biology (Basel). 2015;4:397-423.

94. Holland A, Dowling P, Zweyer M, Swandulla D, Henry M, Clynes M, Ohlendieck K. Proteomic profiling of cardiomyopathic tissue from the aged mdx model of Duchenne muscular dystrophy reveals a drastic decrease in laminin, nidogen and annexin. Proteomics. 2013;13:2312-23

95. Bradford MM. A rapid and sensitive method for the quantitation of microgram quantities of protein utilizing the principle of protein-dye binding. Anal Biochem. 1976;72:248-54.

96. Meleady P, Gallagher M, Clarke C, Henry M, Sanchez N, Barron N, Clynes M. Impact of miR-7 over-expression on the proteome of Chinese hamster ovary cells. J Biotechnol. 2012;160:251-62.

97. Holland A, Dowling P, Meleady P, Henry M, Zweyer M, Mundegar RR, Swandulla D, Ohlendieck K. Label-free mass spectrometric analysis of the $m d x-4 c v$ diaphragm identifies the matricellular protein periostin as a potential factor involved in dystrophinopathy-related fibrosis. Proteomics. 2015;15:2318-31.

98. Murphy S, Zweyer M, Mundegar RR, Henry M, Meleady P, Swandulla $D$, Ohlendieck K. Concurrent label-free mass spectrometric analysis of dystrophin isoform Dp427 and the myofibrosis marker collagen in crude extracts from mdx-4cv skeletal muscles. Proteomes. 2015:3:298-327. 